\title{
Effect of special resistance exercises on extreme forces and some of the mechanical determinants of the stage of disposal and digital achievement of spear competitors *Prof. Dr. Osama Ahmed Mohamed Zaki
}

The world has witnessed a remarkable development in all aspects of life. In all cases, all phenomena have been examined as the proper way to deal with many problems, to identify the many potentials that God has given to mankind and to reach the latest scientific methods.

The spear-throwing competition is one of the field and track contests that requires special physical abilities and preparations because it depends on the muscular ability. This requires the player to use all his powers to maintain the movement of the center of the body weight and to create the working muscles to contract and produce the maximum explosive force of the arm. The same motion path to extrude the instrument to achieve the best digital achievement.(13:366)

It is mentioning "Abu Alaa 'Abd al-Fattah, Ahmad Nasr al-Din" (2003) Exercise is one of the most important means used in the development of various types of muscle strength. These exercises can be divided according to the nature of the resistances practiced by the player between exercises against external resistors (weights, medical balls, dumbbells, sandbags, weights) or exercises using the same body resistance (1: 122)

In the opinion of Mufti Ibrahim Hammad (2000) that the ingredients take some form of resistance to part of the body parts, body weight or resistance to the weight of the body of the colleague practicing, resistance to the mechanical devices of weights, water pressure, sand balls, rubber ropes. (24: 17)

Both khairi el sokary, Mohammed Bureka, (2001 )The concept of force is based on the ability of the muscle to overcome or resist external resistance. The force is the one that supports and enhances the performance and the direct

Assistant Prof , department of theories and application track and field, faculty of physical education for men, Zagazig university

Assiut Journal For Sport Science Arts 
cause of the implementation of many skills. All mathematical skills which lead against resistors are significantly improved by developing and increasing strength.. (7: 63)

Adel Abdul-Basir (1992), Mohamed Hassan Allawi (1992) states that the development of muscle strength is closely related to the development of motor skills The development of athletic performance, performance in all sports activities depends on the efficiency of muscles in the contraction and expansion and the stronger the muscles whenever the contractions more effective, the training programs of the force to include what is more than just lifting weight and include the latest methods and means of development commensurate with the type of muscle work. (2: 5) (20: 8)

Michael H. Stone (2000) points out that muscle strength is a physical element that greatly influences the mechanical properties of motor performance in terms of its kinetic, kinetic, or body parts, according to the requirements of each stage of performance.(16:17)
In order to evaluate any dynamic performance, whether technical or digital, there are three main dimensions through which evaluation the most important of these is the mechanical dimension of its dependence on objective methods of evaluation. The study of the mechanical properties of any skill contributes to the improvement of mathematical technique by correcting and developing it according to the theories and methods of training. (5: 25) (10: 232)

In addition to the fact that the science of biomechanics in the forefront of science, which deals with the study and analysis of motor performance for the purpose of studying the indicators and characteristics of human movement to detect the characteristics of motor performance, it contributes significantly to the evaluation of the effectiveness of different methods and methods of training in terms of the mechanical yield of the player physically and the motor performance of The technical aspect (27: 127)

Mohammed Suleiman Abdullatif (2003) points out that the main field of 
biomechanics is to research the rules, conditions and technical assets of various motor skills in an objective manner and contribute to finding the foundations for the best and most appropriate skill performance by expanding the theoretical information base on the various colors of sports activities for the ability To innovate and achieve the best dynamic achievement $(23: 14)$

The problem of this research is what the researcher observed through what he saw in the training of field and track players and his knowledge of many previous studies and follow-up records at the national level or at the global level. He found that there is weakness in the production of force in particular, especially the force of throwing, This is the weakness of the researcher to several reasons, including weakness in the maximum strength and mechanical variables, as the skill of the spear shaft is subject to the law of projectiles in the sense that there are four factors The speed of departure, the dynamics of the motion of projectiles in the air, and if we look at the first and second workers, they represent fixed conditions that can be controlled, while the speed of the start reflects the amount of force that affects the shaft of the spear The moment of throwing is the most important factors, and the traditional methods of development of force do not provide the muscles of the arm of the rapid pace of contraction appropriate for this type of movement.

So the researcher decided to study this problem and find the scientific solutions and the root methods and advanced methods, namely training with special resistance and knowledge of the impact on the maximum forces and some of the mechanical determinants of the stage of disposal and digital achievement in the spear shaft.

\section{- research goals:}

The purpose of this research is to develop a proposed training program using special resistance training and to know its effect on:

1- the maximum strength in the contest threw the spear in the research sample.

2- Some mechanical determinants of the disposal phase in the spear throwing competition in the sample of the research.

3 - Digital achievement in the spear throwing contest in the research sample. 
- Research hypotheses :

Positive resistance exercises affect positively on:

1 - the maximum strength in the spear throwing contest in the research sample.

2 -some mechanical determinants of the disposal phase in the spear throwing contest in the sample of the research.

3 - Digital achievement in the spear throwing contest in the research sample

- Search terms:

- Resistance training:

The highest strength of the nervous and muscular system to counter the maximum external resistance such as (weights - medical balls - dumbbells - sandbags weight belt) or exercises using the body's own resistance (14: 31)

\section{- Kinetics:}

Is the science that is interested in studying the analytical and mathematical description of the different types of movement, using different variables such as displacement, speed and wheel, which were based on measurements of distance and time without exposure to the causes of motion (27: 129)

- Search procedures.

- Research Methodology.
The researcher used the experimental method using the experimental design of the pretest and the pre-test for one experimental group in order to suit the nature of the study.

The sample of the research: was chosen in a deliberate way from the total research community, which numbered (21) students in the field of athletics in the second grade, third in the secondary school of sport in Zagazig for the academic year 2016/2016 and 10 experimental students were selected. The numerical level of the spear-throwing competition in addition to (7) other students for the pilot experiment, and excluded the number of (4) students for irregular attendance and the following tables (1), (2) describes the characterization and homogeneity of the sample in the variables of growth and physical variables The digital level in research. 
Table (1)

Characterization of the research sample

\begin{tabular}{l|c|c|c|c|c|c|c|c}
\hline \hline \multirow{2}{*}{$\begin{array}{l}\text { a sample } \\
\text { search }\end{array}$} & $\begin{array}{c}\text { Sample exploratory } \\
\text { research }\end{array}$ & \multicolumn{2}{c|}{$\begin{array}{c}\text { Sample experimental } \\
\text { research }\end{array}$} & \multicolumn{2}{c|}{ Excluded } & \multicolumn{2}{c}{ research community } \\
\cline { 2 - 8 } & Number & $\begin{array}{c}\text { Percentage } \\
\%\end{array}$ & Number & $\begin{array}{c}\text { Percentage } \\
\%\end{array}$ & Number & $\begin{array}{c}\text { Percentage } \\
\%\end{array}$ & Number & $\begin{array}{c}\text { Percentage } \\
\%\end{array}$ \\
\hline \hline $\begin{array}{l}\text { research } \\
\text { community }\end{array}$ & 7 & 33.33 & 10 & 47.62 & 4 & 19.05 & 21 & 100 \\
\hline \hline
\end{tabular}

Table (2)

Homogeneity of the total research sample in the growth variables, the training age and the physical tests under study $(N=(17)$

\begin{tabular}{|c|c|c|c|c|c|}
\hline Variables & $\begin{array}{c}\text { measruing } \\
\text { unit }\end{array}$ & SMA & $\begin{array}{r}\text { standard } \\
\text { deviation } \\
\end{array}$ & Mediator & Sprains \\
\hline Age & Year & 16.12 & 0.60 & 16 & 0.59 \\
\hline Length & c.m. & 174.71 & 2.82 & 174 & 0.70 \\
\hline the weight & k.g. & 69.76 & 2.80 & 70 & $.025-$ \\
\hline Training age & Year & 5.18 & 0.73 & 5 & 0.73 \\
\hline $\begin{array}{l}\text { Push a } 3 \mathrm{~kg} \text { medical ball with your } \\
\text { favorite hand }\end{array}$ & $\mathrm{m}$ & 10.62 & 0.11 & 10.60 & 0.47 \\
\hline $\begin{array}{l}\text { Push a medical ball } 3 \mathrm{~kg} \text { by the } \\
\text { hands of the sitting }\end{array}$ & $\mathrm{m}$ & 6.97 & 0.12 & 6.90 & 1.64 \\
\hline $\begin{array}{l}\text { Strength of the muscles of the two } \\
\text { men }\end{array}$ & k.g. & 143.50 & 1.50 & 143.70 & $0.39-$ \\
\hline Strength of back muscles & k.g. & 140.76 & 1.48 & 140.30 & 0.93 \\
\hline The strength of the favorite grip & k.g. & 35.43 & 0.71 & 35.50 & $0.64-$ \\
\hline The digital level of the shaft & $\mathrm{m}$ & 34.35 & 0.58 & 34.32 & 0.17 \\
\hline \multicolumn{2}{|c|}{$\begin{array}{l}\text { It is clear from Table (2) that } \\
\text { all the values of torsion } \\
\text { coefficients for the total } \\
\text { research sample ranged } \\
\text { between ( }-0.64: 1.64) \text { in the } \\
\text { growth and training age } \\
\text { variables. These values were } \\
\text { limited between [3, +3], } \\
\text { indicating that the research }\end{array}$} & $\begin{array}{l}\text { Sal } \\
\text { Th } \\
\text { co } \\
\text { mo } \\
\text { so } \\
\text { Da } \\
\text { Fi } \\
\text { uS } \\
\text { va }\end{array}$ & $\begin{array}{l}\text { ole is ho } \\
\text { e variab } \\
\text { equences } \\
\text { erate rep } \\
\text { ty. } \\
\text { collectior } \\
\text { t: - Instru } \\
\text { to meas } \\
\text { ables: }\end{array}$ & $\begin{array}{l}\text { ogeneous } \\
\text { and } t \\
\text { epresent } \\
\text { entation } \\
\text { ols: } \\
\text { nts and t } \\
\text { the sea }\end{array}$ & $\begin{array}{l}\text { in } \\
\text { eir } \\
\text { a } \\
\text { of } \\
\text { ols } \\
\text { ch }\end{array}$ \\
\hline
\end{tabular}


- Number of spears.

- Dumples and medical balls with sufficient number.

- Rubber slings (Astic).

- Metal measuring tape.

- Flags and signs of control.

- A sufficient number of barriers.

- Box divider (boxes of different height).

- Measuring tape length $50 \mathrm{~m}$

- Chalk and lime.

- Weight Balances in different weights.

- Chalk to draw and measure the wide jump of stability

- Swedish seats used for medical ball test. - Wands, tennis balls, leather ball with handle.

- Stopwatch to measure the time to the nearest $(01,0$ seconds).

- The jacket is a canvas bags filled with sand and different weights.

- Multi-unit weight training device resistors (Smith Barbell)

second: - Instruments and tools for kinetic analysis: Annex (8)

In order to measure the mechanical variables, the researcher used the Motion track program to analyze The shaft of the spear is mechanically driven motion of the video method. The motor analysis unit consists of:

- Cones to select after

cameras. - Group adhesive labels

- Number of (2) VHS videos. - Water balance to adjust the balance of cameras.

- Motion analysis program Motion track. - PC.

- Square meter scale of 1 meter x 1 meter . - Number of (2) tripod holder.

- 2 high-speed video camera 250 cadres / second type Imaging Fastec

Third: Physical tests used in research:

The researcher reviewed a set of specialized references in the test and measurement to find the best tests to measure the maximum muscle capacity and reached the following:

- Test the payment of medical ball $3 \mathrm{~kg}$ by hand favorite. Annex (3)

- Test the payment of a medical ball weight $3 \mathrm{~kg}$ hands of the sitting (m). Annex (4)

- Test measuring the strength of the muscles of the two men with dynamometer $(\mathrm{kg})$.

Annex (5)

- Test the strength of the muscles back with dynamometer (kg). Annex (6) 
- The strength of the preferred fist in the manometer $(\mathrm{kg})$. Annex (7)

\section{Survey Study:}

The researcher conducted the survey during the period from Tuesday 16/2/2016 to Monday, 22/2/2016, on a sample of (7) students from the research community in order to identify the suitability of the proposed program exercises for the sample of the research and to verify the validity of the special imaging procedures And all the instruments used, as well as to verify the tests used in measuring the

\section{Table (3)}

\section{The significance of the differences between the two distinct and non-characteristic groups of the exploratory sample in the} physical tests $n 1=n 2=$ (7)

\begin{tabular}{l|c|c|c|c|c|c}
\hline \multirow{2}{*}{ Physical tests } & \multirow{2}{*}{$\begin{array}{c}\text { Measruing } \\
\text { unit }\end{array}$} & \multicolumn{2}{|c|}{ The Featured group } & \multicolumn{2}{|c|}{$\begin{array}{c}\text { The unmarked } \\
\text { group }\end{array}$} & \multirow{2}{*}{$\begin{array}{c}\text { Value of } \\
\text { "T" }\end{array}$} \\
\cline { 3 - 6 } & $\begin{array}{c}\text { Standard } \\
\text { Mean }\end{array}$ & $\begin{array}{c}\text { Standard } \\
\text { Deviation }\end{array}$ & $\begin{array}{c}\text { Standar } \\
\text { d Mean }\end{array}$ & $\begin{array}{c}\text { Standard } \\
\text { Deviation }\end{array}$ & \\
\hline $\begin{array}{l}\text { Push a 3 kg } \\
\text { medical ball with } \\
\text { your favorite hand }\end{array}$ & meter & 10.81 & 0.13 & 7.02 & 0.22 & \multirow{2}{*}{$6.489^{*}$} \\
\hline $\begin{array}{l}\text { Push a medical } \\
\text { ball 3 kg by the } \\
\text { hands of the } \\
\text { sitting meter }\end{array}$ & 7.03 & 0.12 & 4.69 & 0.16 & \multirow{2}{*}{$5.132^{*}$} \\
\hline $\begin{array}{l}\text { Strength of the } \\
\text { muscles of the two } \\
\text { men Kg }\end{array}$ & 143.26 & 1.26 & 131.76 & 1.89 & \multirow{2}{*}{$8.400^{*}$} \\
\hline $\begin{array}{l}\text { Strength of back } \\
\text { muscles }\end{array}$ & $\mathrm{Kg}$ & 141.47 & 1.90 & 130.24 & 1.74 & $6.539^{*}$ \\
\hline $\begin{array}{l}\text { The strength of } \\
\text { the favorite grip }\end{array}$ & $\mathrm{Kg}$ & 35.53 & 0.77 & 24.56 & 0.69 & $7.125^{*}$ \\
\hline $\begin{array}{l}\text { The digital level } \\
\text { of the shaft }\end{array}$ & $\mathrm{meter}$ & 34.49 & 0.66 & 23.77 & 0.52 & $5.723^{*}$ \\
\hline \hline
\end{tabular}

The value of "T" is tabular at 0.05 and the freedom scores $12=2.179$ Assiut Journal For Sport Science Arts 
Table (3) shows that there are statistically significant differences in the physical tests under study between the distinct group and the non-characteristic group and for the benefit of the characteristic group. The value of the calculated "T" exceeded the value of the table "T" at a significant level of 0.05 , Which indicates the validity of the results of tests of physical characteristics in the search, which means that the ability of these tests to distinguish between the different levels, that they are valid tests to measure the physical attributes for which it was developed.

\section{- Stability:}

To calculate the stability of the tests in question, the researcher used the method of applying the test and applied it to a sample of (7) students from the research community and from outside the original sample with a time difference of (6) days between the two applications. The researcher then found the correlation coefficient between the first and second applications, (4).

\section{Table (4)}

\section{Correlation coefficient between the first and second application of} the ploratory sample in the physical tests $n=(7)$

\begin{tabular}{|c|c|c|c|c|c|c|}
\hline \multirow[b]{2}{*}{ Physical tests } & \multirow[b]{2}{*}{$\begin{array}{c}\text { Measruing } \\
\text { unit }\end{array}$} & \multicolumn{2}{|c|}{ The first application } & \multicolumn{2}{|c|}{ Second Application } & \multirow{2}{*}{$\begin{array}{c}\text { Value of " } \\
\text { The } \\
\text { correlation } \\
\text { coefficient }\end{array}$} \\
\hline & & $\begin{array}{l}\text { Standar } \\
\text { d Mean }\end{array}$ & $\begin{array}{l}\text { Standard } \\
\text { Deviation }\end{array}$ & $\begin{array}{c}\text { Standard } \\
\text { Mean }\end{array}$ & $\begin{array}{l}\text { Standard } \\
\text { Deviation }\end{array}$ & \\
\hline $\begin{array}{l}\text { Push a } 3 \quad \mathrm{~kg} \\
\text { medical ball with } \\
\text { your favorite hand }\end{array}$ & meter & 10.81 & 0.13 & 10.76 & 0.15 & $0.937^{*}$ \\
\hline $\begin{array}{l}\text { Push a medical } \\
\text { ball } 3 \mathrm{~kg} \text { by the } \\
\text { hands of the } \\
\text { sitting }\end{array}$ & meter & 7.03 & 0.12 & 6.93 & 0.21 & $0.898^{*}$ \\
\hline $\begin{array}{l}\text { Strength of the } \\
\text { muscles of the } \\
\text { two men }\end{array}$ & $\mathrm{Kg}$ & 143.26 & 1.26 & 144.12 & 1.84 & $0.930^{*}$ \\
\hline $\begin{array}{l}\text { Strength of back } \\
\text { muscles }\end{array}$ & $\mathrm{Kg}$ & 141.47 & 1.9 . & 140.76 & 2.34 & $0.943^{*}$ \\
\hline $\begin{array}{l}\text { The strength of } \\
\text { the favorite grip }\end{array}$ & $\mathrm{Kg}$ & 35.53 & 0.77 & 34.89 & 0.66 & $0.897^{*}$ \\
\hline $\begin{array}{l}\text { The digital level } \\
\text { of the shaft }\end{array}$ & meter & 34.49 & 0.66 & 35.49 & 1.01 & $0.970^{*}$ \\
\hline
\end{tabular}

The value of "The correlation coefficient " is the tabular at 0.05 and the freedom degrees $5=0.755$ 
Table (4) shows that there is a statistically significant correlation between each of the samples of the exploratory sample in the first application of the physical tests and the second application of the same group for the same period. The correlation coefficient $(t)$ value exceeded the table value at a significant level of 0.05 and scores Freedom 5, which means the stability of test scores when reapplied under the same conditions again.

\section{- Special resistance training} program

Annex (9) proposed:

The training program is one of the most important requirements that the trainers are interested in, especially those that are based on scientific grounds. Without it, the training situation can not be developed. Therefore, the training program represents the backbone of the training process.

(4), (12), (18), (24), and discussion with experts, trainers and similar programs. The researcher determined the period of application of the program (10) training weeks by (3) Training modules per week and this includes the program on (30) training units, the time of each unit (80-90) minutes.

The program aimed to develop the maximum strength and improve the effectiveness of some of the mechanical determinants in order to improve the digital level of the spear-throwing competition in the research sample.

Components of training load for the proposed program:

\section{- Intensity of pregnancy:}

Flackagan S. Baker (2001) and Fleck S.J (Kramer W.J. 2004) agreed that the severity of pregnancy in resistive training ranged from $90 \%$ to $100 \%$ of maximum intensity.

As for the free weights (Kettlebells), they pointed out that the intensity can be determined by the weight of the same tool, where the weights of the balls of medical 1: $6 \mathrm{~kg}$, As for free weights, the weight ranges from $4: 6 \mathrm{~kg}$. (11) (12)

\section{- Load size:}

(2004) noted that the appropriate size in the training should be 4: 6 repetitions, groups of 1: 3 groups and rest periods of 2: 3 minutes between groups. (12)

Divide the parts of the module 


\section{- Warm-up:}

This section aims to prepare the muscles and the circulatory and respiratory systems for the type of muscular work to be carried out within the training unit, focusing on flexibility and lengthening exercises and some general warm-up exercises. The duration of this part is $8-12$ minutes. The intensity of warm-up exercises ranges from 20:30\%.

\section{- Main part:}

This part of the training module contains special resistance exercises that achieve the objective of the unit, which contribute to the improvement of the maximum strength and some mechanical variables of the phase of disposal in the shaft of the spear, and the time of this part represents $75 \%$ of the time of the training module.

\section{- Closing part:}

This part of the light running is relaxed with general stretching exercises, and the researcher has determined the time of this part of $5: 10$ minutes according to the intensity of the load within the main part of the module.

oExecute the search experiment:

\section{Tribal Measurements:}

The tribal measurements of the mechanical variables and the digital level of spearpipe were carried out on Zagazig University Stadium on Wednesday, 24/2/2016 at 4:00 pm after the refraction of the light so as not to affect the efficiency of infrared imaging, where the guidelines for imaging on the joints of the body $(1 \times 1 \times 1)$ in the middle of the end of the approach road to throw the spear in the right hand side of the player's performance where the first camera moved away from the calibration box $7.20 \mathrm{~m}$ distance and the second camera moved away from The calibration box is a distance of 9.80 ( 1 meter) and the second height (1.20 meters). Each player scored three attempts in accordance with the legality of the game. The best attempt was analyzed for each player. Thus, the number of attempts analyzed is 10 attempts. .

Measurements of the maximum force tests were performed on the same pitch the day after the shooting until all the sample players obtained sufficient rest.

- Application of the training program: 
The proposed training program was applied to the members of the research sample during the period from Sunday $28 / 2 / 2016$ to Thursday $5 / 5 / 2016$ for 10 weeks of training at (3) units per week under the supervision of the researcher

\section{. Dimension measurements:}

After the completion of the training program, the researcher carried out the dimension measurements in the same order and conditions of tribal measurements, where the mechanical measurements (photography) and measurement of the digital level of the spear was carried out on Saturday, 7/5/2016 and physical measurements were made the following day.

- Statistical treatments:

The researcher used the appropriate statistical treatment in his research, which is the statistical statistical method. The following statistical processes were used:

1 - arithmetic average

2 - standard deviation

3 - median

4 - spline coefficient

5 - correlation coefficient

6 - test $\mathrm{T}$ percentage improvement rate

The researcher adopted a significant level of 0.05 for statistical significance

- Presentation and discussion of the results:

-First: Showing results: -

Table (5)

The significance of the differences between the pre-test and the test sample in physical tests $N=(10)$

\begin{tabular}{|c|c|c|c|c|c|c|c|}
\hline \multirow{2}{*}{ Physical tests } & \multirow{2}{*}{$\begin{array}{c}\text { Measruin } \\
\text { g } \\
\text { unit }\end{array}$} & \multicolumn{2}{|c|}{ Tribal measurement } & \multicolumn{2}{|c|}{$\begin{array}{c}\text { Dimensional } \\
\text { measurement }\end{array}$} & \multirow{2}{*}{$\begin{array}{c}\text { Average } \\
\text { differenc } \\
\text { e }\end{array}$} & \multirow{2}{*}{$\begin{array}{l}\text { Value } \\
\text { of "T" }\end{array}$} \\
\hline & & Average & $\begin{array}{l}\text { Standard } \\
\text { Deviation } \\
\end{array}$ & $\begin{array}{c}\text { Averag } \\
\text { e } \\
\end{array}$ & $\begin{array}{l}\text { Standard } \\
\text { Deviation } \\
\end{array}$ & & \\
\hline $\begin{array}{l}\text { Push a } 3 \mathrm{~kg} \text { medical ball } \\
\text { with your favorite hand }\end{array}$ & meter & 10.61 & 0.09 & 11.62 & 0.07 & 1.02 & $4.85^{*}$ \\
\hline $\begin{array}{l}\text { Push a medical ball } 3 \mathrm{~kg} \\
\text { by the hands of the } \\
\text { sitting }\end{array}$ & meter & 6.95 & 0.10 & 7.86 & 0.06 & 0.91 & $6.385^{*}$ \\
\hline $\begin{array}{l}\text { Strength of the muscles } \\
\text { of the two men }\end{array}$ & $\mathrm{Kg}$ & 143.98 & 1.35 & 161 & 1.59 & 17.03 & $2.861^{*}$ \\
\hline $\begin{array}{l}\text { Strength of back } \\
\text { muscles }\end{array}$ & $\mathrm{Kg}$ & 140.26 & 1.10 & 150.61 & 1.27 & 10.35 & $5.710^{*}$ \\
\hline $\begin{array}{l}\text { The strength of the } \\
\text { favorite grip }\end{array}$ & $\mathrm{Kg}$ & 35.56 & 0.58 & 42.71 & 0.93 & 7.15 & $4.423^{*}$ \\
\hline
\end{tabular}

The value of $\mathrm{T}$ is the tabular at 0,05 and the freedom scores $9=2.262$ Assiut Journal For Sport Science Arts 
Table 5 shows statistically significant differences in the physical tests between the premeasurement, the telemetry, and the telemetry in the

Table (6)

Percentage improvement in physical variables under study

\begin{tabular}{|c|c|c|c|}
\hline \multicolumn{4}{|c|}{$\begin{array}{r}\text { Table (6) } \\
\text { Percentaga innrovement }\end{array}$} \\
\hline \multirow[b]{2}{*}{ Physical tests } & \multicolumn{2}{|c|}{ Basic group } & \multirow{2}{*}{$\begin{array}{l}\text { Improvemen } \\
\text { t rate } \%\end{array}$} \\
\hline & $\begin{array}{c}\text { Average } \\
\text { tribal }\end{array}$ & \begin{tabular}{c|c} 
Medium \\
dimension
\end{tabular} & \\
\hline $\begin{array}{l}\text { Push a } 3 \mathrm{~kg} \text { medical ball } \\
\text { with your favorite hand }\end{array}$ & 10.11 & 11.62 & $6.52 \%$ \\
\hline $\begin{array}{l}\text { Push a medical ball } 3 \mathrm{~kg} \\
\text { by the hands of the } \\
\text { sitting }\end{array}$ & 6.95 & 7.86 & $13.01 \%$ \\
\hline $\begin{array}{l}\text { Strength of the muscles } \\
\text { of the two men }\end{array}$ & 143.98 & 161 & $11.82 \%$ \\
\hline $\begin{array}{l}\begin{array}{l}\text { Strength } \\
\text { muscles }\end{array} \\
\end{array}$ & 140.26 & 150.61 & $7.38 \%$ \\
\hline $\begin{array}{l}\text { The strength of the } \\
\text { favorite grip }\end{array}$ & 35.56 & 42.71 & $20.11 \%$ \\
\hline \multicolumn{2}{|c|}{$\begin{array}{l}\text { Table (6) shows } \\
\text { differences in the percentage } \\
\text { improvement between the } \\
\text { tribal and basal indices of the } \\
\text { basic group in all the physical } \\
\text { tests of the maximum strength } \\
\text { in the research and the digital }\end{array}$} & \multicolumn{2}{|c|}{$\begin{array}{l}\text { highest differences in the } \\
\text { percentage of improvement in } \\
\text { grip strength was } 20.11 \% \text { and } \\
\text { the least differences In the rate } \\
\text { of improvement in the strength } \\
\text { of the back muscles and } \\
\text { reached } 7.38 \% \text {. }\end{array}$} \\
\hline
\end{tabular}

experimental sample. The value of the calculated $\mathrm{T}$ is greater than the tabular value of $\mathrm{T}$, The degree of freedom 9 .

level of the spear, where the 
Table (7)

Mechanical variables under examination for path of anatomical points (front of hand, elbow, shoulder, center of gravity) During the disposal phase in the spear shaft $N=(10)$

\begin{tabular}{|c|c|c|c|c|c|c|c|}
\hline \multirow{2}{*}{ 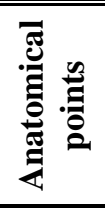 } & \multirow{2}{*}{$\begin{array}{c}\text { Statistical } \\
\text { characterization } \\
\text { Variables } \\
\text { Mechanical }\end{array}$} & \multicolumn{2}{|c|}{$\begin{array}{l}\text { Measurement } \\
\text { tribal }\end{array}$} & \multicolumn{2}{|c|}{$\begin{array}{l}\text { Measurement } \\
\text { Telemetric }\end{array}$} & \multirow{2}{*}{$\begin{array}{c}\text { Average } \\
\text { differences }\end{array}$} & \multirow{2}{*}{$\begin{array}{l}\text { Value } \\
\text { "T." }\end{array}$} \\
\hline & & Average & $\begin{array}{l}\text { standard } \\
\text { deviation }\end{array}$ & Average & $\begin{array}{l}\text { standard } \\
\text { deviation }\end{array}$ & & \\
\hline \multirow{6}{*}{ 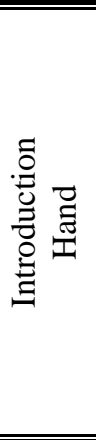 } & $\begin{array}{l}\text { Horizontal } \\
\text { displacement (m) }\end{array}$ & $1.16-$ & 0.04 & $0.78-$ & 0.01 & 0.38 & $3.374^{*}$ \\
\hline & $\begin{array}{l}\text { Horizontal Speed (m / } \\
\text { w) }\end{array}$ & $10.77-$ & 0.01 & $9.97-$ & 0.01 & 0.80 & $8.856^{*}$ \\
\hline & $\begin{array}{l}\text { Horizontal wheel (m / } \\
\mathrm{s} 2)\end{array}$ & 8.64 & 0.53 & 22.16 & 0.75 & 13.52 & $5.613^{*}$ \\
\hline & $\begin{array}{l}\text { Vertical displacement } \\
(\mathrm{m})\end{array}$ & 1.07 & 0.02 & 1.46 & 0.04 & 0.39 & $6.428^{*}$ \\
\hline & Vertical Speed (m/w) & 1.44 & 0.08 & 2.05 & 0.02 & 0.61 & $3.429^{*}$ \\
\hline & $\begin{array}{l}\text { Vertical wheel }(\mathrm{m} / \mathrm{s} \\
2)\end{array}$ & $19.07-$ & 5.79 & $32.11-$ & 0.61 & $13.04-$ & $4.124^{*}$ \\
\hline \multirow{6}{*}{ 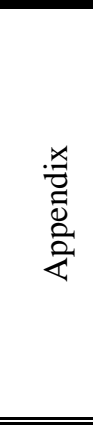 } & $\begin{array}{l}\text { Horizontal } \\
\text { displacement (m) }\end{array}$ & $1.46-$ & 0.02 & $0.92-$ & 0.02 & 0.54 & $5.895^{*}$ \\
\hline & $\begin{array}{l}\text { Horizontal Speed (m / } \\
\text { w) }\end{array}$ & $7.09-$ & 0.02 & $5.71-$ & 0.13 & 1.38 & $3.416^{*}$ \\
\hline & $\begin{array}{l}\text { Horizontal wheel (m / } \\
\text { s 2) }\end{array}$ & 107.04 & 5.15 & 191.05 & 8.16 & 84 & $4.742^{*}$ \\
\hline & $\begin{array}{l}\text { Vertical displacement } \\
(\mathrm{m})\end{array}$ & 1.36 & 0.03 & 1.55 & 0.03 & 0.20 & $2.582^{*}$ \\
\hline & Vertical Speed $(\mathrm{m} / \mathrm{w})$ & 1.22 & 0.02 & 2.05 & 0.02 & 0.83 & 2.079 \\
\hline & $\begin{array}{l}\text { Vertical wheel }(\mathrm{m} / \mathrm{s} \\
2)\end{array}$ & 13.20 & 2.66 & 74.38 & 4.35 & 61.18 & $5.342^{*}$ \\
\hline \multirow{6}{*}{$\frac{\dot{\bar{\theta}}}{\bar{\Xi}}$} & $\begin{array}{l}\text { Horizontal } \\
\text { displacement (m) }\end{array}$ & $1.46-$ & 0.02 & $0.91-$ & 0.04 & 0.55 & $9.534^{*}$ \\
\hline & $\begin{array}{l}\text { Horizontal Speed (m / } \\
\text { w) }\end{array}$ & $4.13-$ & 0.03 & $3.04-$ & 0.03 & 1.09 & $8.466^{*}$ \\
\hline & $\begin{array}{l}\text { Horizontal wheel (m / } \\
\text { s 2) }\end{array}$ & 21.22 & 0.02 & 79.22 & 3.15 & 58 & $7.872^{*}$ \\
\hline & $\begin{array}{l}\text { Vertical displacement } \\
(\mathrm{m})\end{array}$ & 1.18 & 0.03 & 1.37 & 0.02 & 0.19 & $4.021^{*}$ \\
\hline & Vertical Speed (m / w) & 0.35 & 0.02 & 1.12 & 0.01 & 0.78 & 2.154 \\
\hline & $\begin{array}{l}\text { Vertical wheel }(\mathrm{m} / \mathrm{s} \\
\text { 2) }\end{array}$ & 54.18 & 3.95 & 108.22 & 0.06 & 54.04 & $3.331^{*}$ \\
\hline
\end{tabular}


Follow Table (7)

Mechanical variables under examination for path of anatomical points (front of hand, elbow, shoulder, center of gravity) During the disposal phase in the spear shaft $N=(10)$

\begin{tabular}{|c|c|c|c|c|c|c|c|}
\hline \multirow{2}{*}{ 苞 } & \multirow{2}{*}{$\begin{array}{c}\text { Statistical } \\
\text { characterization } \\
\text { Variables } \\
\text { Mechanical }\end{array}$} & \multicolumn{2}{|c|}{$\begin{array}{l}\text { Measurement } \\
\text { tribal }\end{array}$} & \multicolumn{2}{|c|}{$\begin{array}{l}\text { Measurement } \\
\text { Telemetric }\end{array}$} & \multirow{2}{*}{$\begin{array}{c}\text { Average } \\
\text { differences }\end{array}$} & \multirow{2}{*}{$\begin{array}{l}\text { Value } \\
\text { "T." }\end{array}$} \\
\hline & & Average & $\begin{array}{l}\text { standard } \\
\text { deviation }\end{array}$ & Average & $\begin{array}{l}\text { standard } \\
\text { deviation }\end{array}$ & & \\
\hline \multirow{6}{*}{ 范 } & $\begin{array}{l}\text { Horizontal } \\
\text { displacement (m) }\end{array}$ & $1.18-$ & 0.01 & $1.02-$ & 0.01 & 0.16 & $5.144^{*}$ \\
\hline & $\begin{array}{l}\text { Horizontal Speed } \\
(\mathrm{m} / \mathrm{w})\end{array}$ & $2.49-$ & 0.04 & $1.55-$ & 0.02 & 0.94 & $6.352^{*}$ \\
\hline & $\begin{array}{l}\text { Horizontal wheel (m } \\
\text { / s 2) }\end{array}$ & 27.32 & 0.04 & 39.17 & 0.05 & 11.85 & $6.406^{*}$ \\
\hline & $\begin{array}{l}\text { Vertical } \\
\text { displacement (m) }\end{array}$ & 0.78 & 0.02 & 0.86 & 0.02 & 0.08 & $8.384^{*}$ \\
\hline & $\begin{array}{l}\text { Vertical Speed (m / } \\
\mathrm{w})\end{array}$ & 0.13 & 0.01 & 0.73 & 0.03 & 0.60 & $3.135^{*}$ \\
\hline & $\begin{array}{l}\text { Vertical wheel (m / } \\
\mathrm{s} 2)\end{array}$ & 13.05 & 0.03 & 27.37 & 0.02 & 14.32 & $8.682^{*}$ \\
\hline
\end{tabular}

The value of $\mathrm{T}$ is tabular at 0.05 and the freedom scores $9=2.262$

As shown in Table (7) there are statistically significant differences at the level of significance of 0.05 and the degree of freedom (9) between the measurements (tribal, remote) for the benefit of the remote measurement in the research sample in the mechanical variables of the path of the anatomical points ) During the phase of disposal in the spear shaft in the search to the existence of differences of statistical significance at the level of $(0.05 \%)$ between the measurements (tribal, dimension) for the benefit of remote measurement in the research sample in the mechanical variables in question except the variable (vertical velocity of the facility, vertical speed of the shoulder). 
Table (8)

Mechanical variables under examination for the path of the anatomical points (pelvis, knee, foot) during the disposal phase of the spear shaft $N=(10$

\begin{tabular}{|c|c|c|c|c|c|c|c|}
\hline \multirow{2}{*}{ 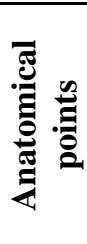 } & \multirow{2}{*}{$\begin{array}{l}\text { Statistical } \\
\text { characterizat } \\
\text { ion } \\
\text { Variables } \\
\text { Mechanical }\end{array}$} & \multicolumn{2}{|c|}{$\begin{array}{c}\text { Measurement } \\
\text { tribal }\end{array}$} & \multicolumn{2}{|c|}{$\begin{array}{c}\text { Measurement } \\
\text { Telemetric }\end{array}$} & \multirow[b]{2}{*}{$\begin{array}{c}\text { Average } \\
\text { differenc } \\
\text { es }\end{array}$} & \multirow[b]{2}{*}{$\begin{array}{l}\text { Value } \\
\text { "T.". }\end{array}$} \\
\hline & & Average & $\begin{array}{c}\text { standa } \\
\text { rd } \\
\text { deviati } \\
\text { on }\end{array}$ & Average & $\begin{array}{l}\text { standard } \\
\text { deviation }\end{array}$ & & \\
\hline \multirow{6}{*}{$\frac{n}{2}$} & $\begin{array}{l}\text { Horizontal } \\
\text { displacement } \\
(\mathrm{m})\end{array}$ & $2.14-$ & 2.82 & $0.97-$ & 0.03 & 1.17 & $7.721^{*}$ \\
\hline & $\begin{array}{l}\text { Horizontal } \\
\text { Speed }(\mathrm{m} / \mathrm{w})\end{array}$ & $2.32-$ & 0.07 & $1.86-$ & 0.05 & 0.46 & $8.478^{*}$ \\
\hline & $\begin{array}{l}\text { Horizontal } \\
\text { wheel }(\mathrm{m} / \mathrm{s} \\
\text { 2) }\end{array}$ & 12.71 & 0.73 & 26.15 & 1.91 & 13.45 & $8.194^{*}$ \\
\hline & $\begin{array}{l}\text { Vertical } \\
\text { displacement } \\
(\mathrm{m})\end{array}$ & 0.81 & 0.02 & 0.93 & 0.01 & 0.12 & $5.101^{*}$ \\
\hline & $\begin{array}{l}\text { Vertical } \\
\text { Speed }(\mathrm{m} / \mathrm{w})\end{array}$ & 0.55 & 0.02 & 0.97 & 0.01 & 0.42 & $3.585^{*}$ \\
\hline & $\begin{array}{l}\text { Vertical } \\
\text { wheel (m / s } \\
\text { 2) }\end{array}$ & 2.56 & 0.53 & 15.25 & 0.33 & 12.69 & $6.936^{*}$ \\
\hline \multirow{4}{*}{$\stackrel{\otimes}{\Xi}$} & $\begin{array}{l}\text { Horizontal } \\
\text { displacement } \\
(\mathrm{m})\end{array}$ & $1.05-$ & 0.01 & $0.92-$ & 0.01 & 0.13 & $8.685^{*}$ \\
\hline & $\begin{array}{l}\text { Horizontal } \\
\text { Speed }(\mathrm{m} / \mathrm{w})\end{array}$ & $2.02-$ & 0.02 & $1.03-$ & 0.01 & 0.99 & $7.989^{*}$ \\
\hline & $\begin{array}{l}\text { Horizontal } \\
\text { wheel }(\mathrm{m} / \mathrm{s} \\
\text { 2) }\end{array}$ & 93.35- & 3.80 & $35.02-$ & 1.87 & 58.33 & $4.713^{*}$ \\
\hline & $\begin{array}{l}\text { Vertical } \\
\text { displacement } \\
\text { (m) }\end{array}$ & 0.49 & 0.01 & 0.56 & 0.01 & 0.08 & $8.735^{*}$ \\
\hline
\end{tabular}


Follow Table (8)

Mechanical variables under examination for the path of the anatomical points (pelvis, knee, foot) during the disposal phase of the spear shaft $N=(10$

\begin{tabular}{|c|c|c|c|c|c|c|c|}
\hline \multirow{2}{*}{ 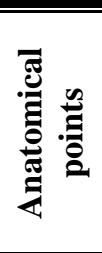 } & \multirow{2}{*}{$\begin{array}{l}\text { Statistical } \\
\text { characterizat } \\
\text { ion } \\
\text { Variables } \\
\text { Mechanical }\end{array}$} & \multicolumn{2}{|c|}{$\begin{array}{c}\text { Measurement } \\
\text { tribal }\end{array}$} & \multicolumn{2}{|c|}{$\begin{array}{c}\text { Measurement } \\
\text { Telemetric }\end{array}$} & \multirow[b]{2}{*}{$\begin{array}{l}\text { Average } \\
\text { differenc } \\
\text { es }\end{array}$} & \multirow[b]{2}{*}{$\begin{array}{l}\text { Value } \\
\text { "T." }\end{array}$} \\
\hline & & Average & $\begin{array}{c}\text { standa } \\
\text { rd } \\
\text { deviati } \\
\text { on }\end{array}$ & Average & $\begin{array}{l}\text { standard } \\
\text { deviation }\end{array}$ & & \\
\hline & $\begin{array}{l}\text { Vertical } \\
\text { Speed }(\mathrm{m} / \mathrm{w})\end{array}$ & 0.33 & 0.01 & 0.89 & 0.01 & 0.56 & $5.542^{*}$ \\
\hline & $\begin{array}{l}\text { Vertical } \\
\text { wheel (m / s } \\
\text { 2) }\end{array}$ & 21.32 & 3.09 & 47.42 & 1.43 & 26.10 & $4.169^{*}$ \\
\hline \multirow{6}{*}{$\begin{array}{l}\overrightarrow{0} \\
\dot{0}\end{array}$} & $\begin{array}{l}\text { Horizontal } \\
\text { displacement } \\
(\mathrm{m})\end{array}$ & $0.73-$ & 0.02 & $0.46-$ & 0.02 & 0.27 & $6.767^{*}$ \\
\hline & $\begin{array}{l}\text { Horizontal } \\
\text { Speed }(\mathrm{m} / \mathrm{w})\end{array}$ & $2.81-$ & 0.02 & $1.94-$ & 0.01 & 0.87 & $8.253^{*}$ \\
\hline & $\begin{array}{l}\text { Horizontal } \\
\text { wheel (m / s } \\
\text { 2) }\end{array}$ & 19.59 & 1.12 & 38.41 & 1.73 & 18.82 & $3.980^{*}$ \\
\hline & $\begin{array}{l}\text { Vertical } \\
\text { displacement } \\
(\mathrm{m})\end{array}$ & 0.27 & 0.01 & 0.33 & 0.01 & 0.06 & $7.333^{*}$ \\
\hline & $\begin{array}{l}\text { Vertical } \\
\text { Speed }(\mathrm{m} / \mathrm{w})\end{array}$ & 0.11 & 0.01 & 0.68 & 0.02 & 0.57 & $5.995^{*}$ \\
\hline & $\begin{array}{l}\text { Vertical } \\
\text { wheel (m / s } \\
\text { 2) }\end{array}$ & $16.26-$ & 0.03 & $3.78-$ & 0.02 & 12.48 & $4.143^{*}$ \\
\hline
\end{tabular}

The value of "T" is tabular at 0.05 and the freedom scores $9=2,262$

Table (8) shows that there are statistically significant differences in the mechanical variables of the path of the anatomical points (pelvic-kneefoot) during the disposal phase of the spear shaft in the study between the tribal measurement and the telemetry. The value of "T" calculated is greater than the value of the "T" table at a significant level of 0.05 , and the degree of freedom 9 . 
Table (9)

The significance of the differences between the measurement of the tribal and the variance in the angular change of the anatomical body points in the phase of disposal of the spear spear competition is in search $N=(10)$

\begin{tabular}{|c|c|c|c|c|c|c|c|}
\hline \multirow[t]{2}{*}{ Variables } & \multirow{2}{*}{$\begin{array}{c}\text { measruing } \\
\text { unit }\end{array}$} & \multicolumn{2}{|c|}{$\begin{array}{c}\text { Tribal } \\
\text { measurement } \\
\end{array}$} & \multicolumn{2}{|c|}{ Telemetry } & \multirow{2}{*}{$\begin{array}{c}\text { Average } \\
\text { difference } \\
\text { s } \\
\end{array}$} & \multirow{2}{*}{$\begin{array}{l}\text { Values } \\
\text { " T" }\end{array}$} \\
\hline & & Average & deviation & Average & deviation & & \\
\hline $\begin{array}{l}\text { Angle of hand } \\
\text { introduction }\end{array}$ & Degree & 171.17 & 0.28 & 202.19 & 0.08 & 32.02 & $6.011^{*}$ \\
\hline $\begin{array}{ll}\text { Angle } & \text { of } \\
\text { attachment }\end{array}$ & Degree & 132.54 & 0.20 & 186.09 & 0.09 & 53.55 & $7.629^{*}$ \\
\hline Shoulder angle & Degree & 152.14 & 0.19 & 179.14 & 0.27 & 27 & $5.331^{*}$ \\
\hline Angle of the tub & Degree & 189.65 & 0.18 & 209.57 & 1.05 & 19.93 & $7.244^{*}$ \\
\hline Knee angle & Degree & 204.40 & 0.86 & 213.05 & 0.47 & 8.65 & $3.749^{*}$ \\
\hline Angle of foot & Degree & 127.44 & 0.19 & 143.22 & 0.65 & 15.77 & $5.144^{*}$ \\
\hline $\begin{array}{ll}\begin{array}{l}\text { Spear } \\
\text { angle }\end{array} & \text { starting } \\
\end{array}$ & Degree & 46.24 & 0.58 & 41.35 & 0.73 & 4.88 & $7.101^{*}$ \\
\hline
\end{tabular}

The value of $\mathrm{T}$ is tabular at 0.05 and the freedom scores $9=2.262$
Table
9
shows
measurement and the telemetry

statistically significant differences in the angular variation of the anatomical body points in the phase of elimination of the skill of the spear shaft in the study between the tribal and for the sake of the telemetry in the experimental sample. The calculated value of $\mathrm{T}$ is greater than the value "T" table at a significant level of 0.05 , the degree of freedom

Table (10)

The significance of the differences between the tribal and algebraic measurement of the experimental group in the numerical level of the spear spear $n=(10)$

\begin{tabular}{c|c|c|c|c|c|c|c}
\hline \hline \multirow{2}{*}{$\begin{array}{c}\text { Variab } \\
\text { les }\end{array}$} & $\begin{array}{c}\text { measruing } \\
\text { unit }\end{array}$ & \multicolumn{2}{|c|}{$\begin{array}{c}\text { Tribal } \\
\text { measurement }\end{array}$} & \multicolumn{2}{|c|}{$\begin{array}{c}\text { Dimensional } \\
\text { measurement }\end{array}$} & $\begin{array}{c}\text { Average } \\
\text { differences }\end{array}$ & $\begin{array}{c}\text { Value of } \\
\text { "T" }\end{array}$ \\
\cline { 3 - 6 } & Average & $\begin{array}{c}\text { Standard } \\
\text { Deviation }\end{array}$ & Average & $\begin{array}{c}\text { Standard } \\
\text { Deviation }\end{array}$ & \\
\hline \hline $\begin{array}{c}\text { The } \\
\text { digital } \\
\text { level } \\
\text { of the } \\
\text { shaft }\end{array}$ & meter & 34.19 & 0.51 & 36.42 & 0.27 & 2.24 & 4.466 \\
\hline \hline
\end{tabular}

The value of $\mathrm{T}$ is the tabular at 0,05 and the freedom scores $9=2.262$ 
Table (10) shows that there are statistically significant differences between the measurement of the tribal, the artefact and the dimension of the dimension in the numerical level. The value of the calculated " $T$ " exceeded the value of the " $t$ " in the table at a significant level of 0.05 and the degree of freedom 9.

Table (11)

The improvement ratios between the tribal and the tribal measurement Experimental at the digital level of spearpipe $n=(10)$

\begin{tabular}{|c|c|c|c|c|}
\hline \multirow[b]{2}{*}{ Variables } & \multirow{2}{*}{$\begin{array}{c}\text { measruing } \\
\text { unit }\end{array}$} & \multicolumn{2}{|c|}{ Basic group } & \multirow{2}{*}{$\begin{array}{l}\text { Improvement } \\
\text { rate \% }\end{array}$} \\
\hline & & $\begin{array}{c}\text { Average } \\
\text { tribal }\end{array}$ & $\begin{array}{c}\text { Medium } \\
\text { dimension }\end{array}$ & \\
\hline $\begin{array}{l}\text { The digital } \\
\text { level } \\
\text { of the shaft }\end{array}$ & meter & 34.19 & 36.42 & $6.52 \%$ \\
\hline
\end{tabular}

It is seen from the table (11) and having ratios improved in the digital variable level, reaching $6.52 \%$

Second, discuss the results: -

- discuss the results for the first goal: -

Table 5 shows statistically significant differences in the physical tests between the premeasurement, the telemetry, and the telemetry in the experimental sample. The value of the calculated $T$ is greater than the tabular value of $\mathrm{T}$, and the degree of freedom 9 .

The researcher attributed the reason for these differences to the impact of the proposed training program using resistance exercises, which had a positive and effective role in the development of the maximum force in addition to being closer to the nature of the performance of the skill of the spear shaft.

These results are consistent with Ahlam Sadiq's (2006) (3) finding that the experimental program used in the method of training variable resistors has clearly influenced the characteristics of the rapid force and explosive force of the training group better than the control group, which included various weight resistance exercises Body and weight added to the body, and also agree with the reach of Mohamed Amin Hamid Abdul Karim, 2015 (18), where he found that the proposed training program using Assiut Journal For Sport Science Arts 
resistance exercises had a positive effect on the physical variables in the research sample in the spear spear contest, Mohamed El Sayed Mostafa (2015) (19) where he found that the quality of training Albulaomitrih positively affected the maximum muscular ability of the arms and legs of the sample in question.

Table (6) shows differences in the percentage improvement between the tribal and the base groups in all the physical tests of the maximum force in question and the digital level of the spear. The strength test of the favorite grip recorded the highest improvement rate $(20.11 \%)$, (3.38\%). The tests also included a 3-kg medical ball with the preferred hand, a medical ball of $3 \mathrm{~kg}$ in the hands of the legs, and a strength of the muscles of the legs $(9.52 \%, 13.01) . \%$, $11.82 \%)$ respectively. this improvement was attributed to the researcher proposed training program for Use resistance training for which has been applied to the sample and the impact on individuals improve distance javelin throw competition in the search.
These results are consistent with the findings of Ahlam Sadeq (2006)(3), Muhammad Amin Hamed Abdulkarim (2015)(18), Mohamed El Sayed Mustafa (19), Basant Said Khalil (2008)(6), where they reached The training program using resistors led to an improvement in all physical and skill variables.

This is confirmed by "Abul Alaa Abdel-Fattah, Ahmed Nasr El-Din" (2003) that exercise is one of the most important means used in the development of muscle strength of different types can be divided by these exercises depending on the nature of the resistance that the player is trained between exercises against external resistors (weights - Dumbles - sandbags - weight wrestling) or exercises using the same object resistance. (1: 122)

It is clear in the researcher that the proposed training program using resistance training has improved the physical tests that show the maximum strength in the research of the members of the research sample, thus achieving the first goal and verifying the validity of the 
first hypothesis The text of "Positive resistance exercises positively affect the maximum strength in the spear throwing contest I have a sample search."

- Discuss the results of the second objective: -

Table (7) shows that there are statistically significant differences at the level of significance of 0.05 and the degree of freedom (9) between the measurements (tribal and remote) for the benefit of remote measurement in the research sample in the mechanical variables of the path of the anatomical points During the phase of disposal in the spear shaft in the research, there were statistically significant differences at the level of $(0.05 \%)$ between the measurements (the tribal and the remote) in favor of the remote measurement in the research sample in the mechanical variables in question except the variable (vertical velocity of the facility, .

The researcher attributed the reason for these differences to the effect of the proposed training program using special resistance training, which had a positive and effective role in the development of selected mechanical variables during the phase of disposal.

This is in line with what Ayman Ahmed Mohamed El Badrawy (2015)(4) indicated that the qualitative exercises positively affected the biomechanical indicators and the starting indicators of the spear spear. Moreover, there was a correlation between some biomechanical and digital indicators. It is also consistent with what Muhammad Ahmad Ramzi Badran (2007)(17) indicated that the training program had a positive impact on the development of some mechanical properties of the spear arm in the spearthrowing competition.

This is confirmed by Sadiq Ahmed Salam (2014) (25) that there are different factors have an effective impact on raising the level of the spear in the spear, including the speed of hand to leave the shaft and increasing speed and length of the trajectory and straightness of the spear, and angle of throwing and air.

Jamal Al-Din and Anwar Al-Sabbagh (2009) point out that any movement can only 
take place with the participation of the whole body, but this participation is not done at one time or at a single speed. The human body contains many joints that move the body to different bodies in different forms(15.: 106).

The researcher attributed the existence of mechanical variables not statistically significant to the fact that these variables are more related to the skillful performance of the contest subject of the research and mastery requires a greater increase in the number of training modules in the program, and then focus on the skill part.

Table (8) shows that there are statistically significant differences in the mechanical variables of the path of the anatomical points (pelvic-kneefoot) during the disposal phase in the spear shaft in question between the tribal measurement and the telemetry. The value of "T" calculated is greater than the value of the "T" table at a significant level of 0.05 , and the degree of freedom (9).

The researcher attributed the reason for these differences to the effect of the proposed training program using special resistance training, which had a positive and effective role in the development of selected mechanical variables during the phase of disposal.

These results are in line with the findings of Ayman Ahmed Mohamed El Badrawy (2015) (4), Mohamed Ahmed Ramzy Badran (2007) (17) where they concluded that the training program had a positive effect on the development of the mechanical characteristics and starting indicators of the spear spear

And also with what they referred to as "Sulaiman Ali Hassan et al." In 1983. They pointed out that getting the most strength for the moment of elimination in the throwing competitions depends on the longer distance in which the muscles of the shoulders, chest, back, pelvis and legs work at the moment of payment. (26 :228)

Table 9 shows statistically significant differences in the angular variation of the anatomical body points in the phase of elimination of the skill of the spear shaft in the study between the tribal measurement and the telemetry 
and for the sake of the telemetry in the experimental sample. The calculated value of " $T$ is greater than the value "T" table at a significant level of 0.05 , the degree of freedom (9).

These results are consistent with the findings of Michael $\mathrm{H}$. Stone 2000 that muscle strength is a physical element that greatly influences the mechanical properties of kinetic performance in terms of its kinetic, kinetic, or body parts, according to the requirements of each stage of performance (16: 17)

And also with what Talha Hossam El-Din et al. (1998) pointed out that achieving the largest horizontal distance in throwing competitions depends primarily on both the speed at which the tool can be obtained and the angle of its launch (27: 176)

As noted above, "Dyson Jeoffery" (2000) pointed out that when the movement takes place around the axis of the joint, the movement energy takes an angle dye and in the same way the angular momentum can be increased by increasing the angular velocity.(9: 42)

The second objective was to verify the validity of the second hypothesis, which states that "Special resistance exercises positively affect some of the mechanical determinants of the disposal stage in the spear-throwing contest in the sample."

\section{- Discuss the results of the} third objective: -

Table (10) shows that there are statistically significant differences between the measurement of the tribal and the arithmetic and the dimension of the dimension at the numerical level, where the value of the calculated " $\mathrm{T}$ " exceeded the value of "T" table at a significant level of 0.05 , and the degree of freedom (9).

The researcher attributed the reason for these differences to the effect of the proposed training program using resistance training which had a positive and effective role in developing the digital level of Assiut Journal For Sport Science Arts 
the spear throwing competition for the sample in question.

These results are in line with the findings of Mohamed Amin Hamid Abdulkarim,(2015) (18). $\quad \mathrm{He}$ concluded that the proposed training program using resistance training had a positive effect on the numerical level in the research sample in the spear spear competition, Mohamed El Sayed Mostafa, (2015)(19) where it was found that the biometric training exercises positively affected the digital level in the spear shaft of the sample in question and also agreed with the reach of Ayman Ahmed Mohamed El Badrawy (2015) (4), Mohamed Ahmed Ramzy Badran (2007) (17) Where they concluded that the training program had a positive impact on the development of the digital level of the arm Mi to throw the spear.

Table (11) shows an improvement in the digital level variable of the spear spear competition where the improvement rate was $6.52 \%$
The researcher attributed the reason for the improvement to the effect of the proposed training program using the resistance training which had a positive and effective role in developing the digital level of the skill of throwing the spear.

These findings are consistent with the findings of the mechanisms of Mohamed Amin Hamed Abdul-karim (2015)(18), Mohamed El Sayed Mustafa (19), Ayman Ahmed Mohamed El Badrawy (2015) (4), Mohamed Ahmed Ramzy Badran (2007) where All these researchers concluded that the training programs under their research led to a slight improvement in the numerical level of the members of the research sample used.

In the tables (10.11), the third objective was achieved and the third hypothesis was confirmed, which states that "the special resistance exercises positively affect the digital achievement in the spear-throwing competition in the sample 
- Conclusions and

Recommendations:

First: Abstracts:

Within the limits of the research sample and the proposed training program using the functional exercises. In the light of the results referred to, the researcher reached the following conclusions:

1- The proposed training program using special resistance training has a positive effect on the physical tests that show the maximum strength in the research sample in the spear throwing competition.

2 - The proposed training program using special resistance training has a positive course in improving the physical tests that show the maximum strength in the spear throwing contest in the research sample.

3- The proposed training program using special resistance training has a positive effect on some mechanical characteristics of the disposal phase in the research sample in the spear shaft competition except for variable (vertical velocity of the facility, vertical speed of the shoulder).

4- The proposed training program using special resistance training has a positive course in improving some of the mechanical characteristics of the phase of disposal in the research sample in the spear throwing contest.

5- The proposed training program using special resistance training has a positive effect on the digital achievement of the sample in the spear spear competition.

6- The proposed training program using special resistance training has a positive course in improving the digital achievement of the sample in the spear spear competition.

Second: Recommendations:

In light of the results and conclusions, the researcher recommends the following:

1- The use of resistance training for Egyptian spear- 
throwers because of its importance in developing the maximum power on the one hand, and the development and mechanical determinants on the other hand.

2- Guided by the content of the training program resistance proposed in the development of similar exercises using various tools and the regulation of training loads for this type of training.

3. The quantitative values of the mechanical determinants during the disposal phase of the spear shaft are guided as one of the scales in which the mechanical performance of a similar sample can be evaluated.

4 - the need to put trainers in the games of strength in their training (special resistance training)

\section{References:}

1- Abu Alaa Abdel-Fattah and Ahmad Nasr El-Din: physiology of fitness, 2, Arab Thought House, Cairo, 2003.

2- Adel Abdul Basir: Sport and the integration of theory and practice, United Library, Port Fouad, 1992.

3- Ahlam Sadiq: The impact of the method of training the changing resistors in the development of some functional indicators, physical and mechanical achievement of the enemy $200 \mathrm{~m}$, International Academy of Science and Sports, Mansoura University, 2006.

\section{4- Ayman Ahmed}

Mohammed Al- Badrawy: Specific exercises as a function to develop the mechanical efficiency of the ramming arm and the digital level of spearpipe ", Journal of Physical Education Research, Volume 52, No. 99, Part V, Faculty of Physical Education Boys, Zagazig University,2015.

5- Barrow, MJ Lee: Mechanical Kinesiology, 2nd ed., C.V. mosly comp, sant Louis, USA, 2000.

6- Bassent Said Khalil: The impact of the use of resistance ligaments on the development of some elements of physical fitness and the level of digital short distance competitions 
(100 m, $200 \mathrm{~m})$, Master thesis, unpublished, Faculty of Physical Education Girls Aljazeera, Helwan

University,2014.

7- Charity Ibrahim AlSukari and Mohammed Jaber Bureka: Integrated Training Series for the Hero Industry 6-18 years, Part I, Knowledge Establishment, Alexandria, 2001.

8- Delecluse: the effect of high resistance traning and high velocity on trining of acceleration, internet mdatbank ,1999.

9- Dyson Geoffrey, H.: Dyson's mechanics of athletics ,9th ed., Biddles, L.T.D. Guilford, London, 2000.

10- Elliot, BH John: Measurements concept in physical education, Human Kinetics Champing, California, USA, 1992.

\section{1- Flanagan S. Baker:} Improve performance with ballistic training, American Journal of sports science, vol. (22) University of Ontario, Canada, 2001.

\section{2- Fleck , S.J and Kramer,} W.J: Designing resistance training program, 3rd ed., Human Kinetics Champaign, New York, USA, 2004.

\section{3- Gerhardt Schmolinsky:} Track and Field, 3rd ed., sport verlage, Berlin, 2000

14- Harre,D, : Enifuhrug in die allgemine training ,su . wetkamp flehre, leipzing ,1980.

15- Jamal Mohammed Alaa Eddin, Nahed Anwar Sabbagh: Movement Science, tenth edition, Dar Al-Fikr Book, Alexandria, 2009.

16- Michael H. Stone: Athletic Performance development, strength and Conditioning, sport science Journal volume (20) Saint Louis, USA, 1998.

\section{7- Mohamed Ahmed Ramzy}

Badran: Effect of Ballistic Training on Maximum Muscle Power and Some Mechanical Properties of the Spear Arm, Physical Education Research Journal, Vol. 40, No. 76A, Faculty of Physical Education Boys, Zagazig University, 2007 
18- Mohamed Amin Hamed Abdel-Karim: The Effect of Using Resistance Exercises on Improving Some Special Physical Capacities and Digital Level of Beginners in Spear Throw, Journal of Physical Education Research, Volume 51, Number 97, Part 2, Faculty of Physical Education Boys, Zagazig University, April 2015 .19- Mohamed El Sayed Mostafa: The Effect of Biometric Workouts on the Maximum Muscle Power and Digital Level of Shaft Throwers ", Journal of Physical Education Research, Vol. 52, Number 99, Vol. 5, Faculty of Physical Education, Benin, Zagazig University,2015.

20- Mohamed Hassan Allawi:

Mathematical Training

Science, I 13, Dar Al Ma'aref, Cairo, 1992.

21- Mohamed Hassan Allawi, Mohamed Nasr El-Din Radwan: tests of motor performance, Cairo, Arab Thought House, Cairo, 2001.
22- Mohamed Sobhy

Hassanein: Measurement and Evaluation in Physical Education and Sports, Dar AlFikr Al-Arabi, Cairo 2001.

\section{3- Mohammed Suleiman}

Abdullatif: Processing of Biomechanics for Measuring Motor Performance, 1, United Press, Port Said, 2003.

\section{4- Mufti Ibrahim Hammad:}

Founding the development of muscle strength resistors for children in the primary and preparatory stages, the Center for the book of publishing, Cairo, 2000.

25- Sadaqi Salam: Athletics, 1, Modern Book Center, Cairo, 2014

26- Sulaiman Ali Hassan et al.: Scientific Analysis of Field and Field Competitions, Dar Al Ma'aref, Cairo, 1983.

\section{7-Talha Hossam El-Din et}

al.: Movement Applied Science, Part I, The Book Center for Publishing, Cairo, 1998. 